\title{
PENDIDIKAN KARAKTER DI MADRASAH IBTIDAIYAH MODERN SAHID, BOGOR, JAWA BARAT
}

\author{
Sumarsih Anwar \\ Peneiti Balai Litbang Agama Jakarta \\ Jl. Rawa Kuning No.6 Pulo Gebang Cakung Jakarta | Email: Sumarsih.anwar@yahoo.com
}

\begin{abstract}
This study aims to know (1) opinion and policy of principal of Sahid Modern Madrasah Bogor on character education (2) implementation of character education in Sahid Modern MI Bogor and (3) evaluation and assessment of character values. This study is a case study done at Sahid Modern MI Bogor, West Java using qualitative approach. The main instruments are interview, observation technique and documented study. The findings are (1) Principal of Sahid Modern MI Bogor believes that Islam already had a more comprehensive term than character education namely akhlakul karimah (good moral). Madrasah is not only responsible in producing students that excel in science and technology but also Islamic character and personality. (2) Character education is done by integrating values of character in every subject, intra curriculum and extra curriculum subject and culture development and (4) evaluation and assessment of attitude and behavior (values of akhlakul karimah) is done by teacher by observing the students at school when students are at school.
\end{abstract}

Keywords: character education, Madrasah Ibtidaiyah

\begin{abstract}
Abstrak
Penelitian ini bertujuan mengetahui: (1) pandangan dan kebijakan kepala Madrasah Ibtidaiyah (MI) Moderen Sahid Bogor mengenai pendidikan karakter; (2) implementasi pendidikan karakter di MI Moderen Sahid Bogor; dan (3) cara evaluasi dan penilaian nilai-nilai karakter. Penelitian ini merupakan penelitian kasus yang dilakukan di MI Moderen Sahid Bogor Jawa Barat, dengan menggunakan pendekatan kualitatif. Instrumen utamanya adalah wawancara, dan juga menggunakan teknik observasi, serta studi dokumentasi. Temuan penelitiannya adalah: (1) Kepala MI Moderen Sahid Bogor berpandangan bahwa dalam agama Islam sudah ada istilah yang lebih komprehensif dibanding pendidikan karakter itu sendiri yakni akhlakul karimah (akhlak mulia). Madrasah tidak hanya bertanggungjawab dalam mencetak peserta didik yang unggul dalam ilmu pengetahuan dan teknologi, tetapi yang lebih penting adalah pembentukan jati diri, karakter dan kepribadian yang Islami (akhlakul karimah); (2) pendidikan karakter (akhlakul karimah) dilakukan melalui pengintegrasian nilai-nilai karakter pada setiap mata pelajaran, kegiatan intrakurikuler, dan ekstrakurikuler, serta pengembangan budaya sekolah; dan (4) evaluasi dan penilaian terhadap sikap dan perilaku (nilai-nilai karakter akhlakul karimah) dilakukan guru melalui teknik observasi terhadap peserta didik sehari-hari di lingkungan sekolah yang dilakukan setiap saat selama peserta didik di sekolah.
\end{abstract}

Kata Kunci: pendidikan karakter, Madrasah Ibtidaiyah

Naskah diterima 22 Oktober 2014. Revisi pertama, 16 November 2014. Revisi kedua, 19 November 2014 dan revisi terakhir 2 Desember 2014 


\section{PENDAHULUAN}

Banyaknya peristiwa perkelahian dan tawuran antar pelajar, konflik antar komunitas, ketidakadilan serta kebohongan-kebohongan yang terjadi di masyarakat kita, menyiratkan seolah-olah bangsa ini tidak mempunyai karakter. Bahkan di tingkat pemegang kekuasaan dan pembuat kebijakan, nyaris tak mencerminkan sebuah karakter diri sebagai makhluk Tuhan dan sosial. Pada hal, karakter sebagai cara berpikir dan berperilaku menjadi ciri khas tiap individu dalam kehidupan antar sesama, baik dalam lingkup keluarga, masyarakat, bangsa, dan negara. Untuk itu diperlukan individu-individu yang berkarakter baik yang bisa membuat keputusan dan siap mempertanggungjawabkan tiap akibat dari keputusan yang ia perbuat.

Setiap individu sudah memiliki potensi karakter yang baik sebelum dilahirkan, dan potensi tersebut harus terus-menerus dibina melalui sosialisasi dan pendidikan sejak usia dini. Karakter merupakan kualitas moral dan mental seseorang yang pembentukannya dipengaruhioleh faktorbawaan (fitrah-natural) dan lingkungan (sosialisasi atau pendikannatural). Pendidikan merupakan salah satu wadah dalam menunjang pembentukan karakter tiap individu. Sekolah dasar adalah merupakan pendidikan awal penanaman karakter anak dalam perkembangan dirinya. Tak bisa kita mungkiri bahwa banyaknya generasi di Indonesia, yang tidak mengenal dirinya sebagai bangsa Indonesia-yang memiliki berbagai macam suku, budaya, dan kultur sosial yang berbeda.

Meskipun semua pihak bertanggungjawab atas pendidikan karakter calon generasi penerus bangsa (anak-anak), namun keluarga merupakan wahana pertama dan utama bagi pendidikan karakter anak. Untuk membentuk karakter anak, keluarga harus memenuhi tiga syarat dasar bagi terbentuknya kepribadian yang baik. Yaitu,maternal bonding, rasa aman, stimulasi fisik dan mental. Selain itu, jenis pola asuh yang diterapkan orang tua kepada anaknya juga menentukan keberhasilan pendidikan karakter anak di rumah. Kesalahan dalam pengasuhan anak di keluarga akan berakibat pada kegagalan dalam pembentukan karakter yang baik.

Namun bagi sebagian keluarga, barangkali proses pendidikan karakter yang sistematis di atas sangat sulit, terutama bagi sebagian orang tua yang terjebak pada rutinitas yang padat. Karena itu, seyogyanya pendidikan karakter juga perlu diberikan saat anak-anak masuk dalam lingkungan sekolah, terutama sejak play group dan taman kanak-kanak. Di sinilah peran guru, yang dalam filosofi Jawa disebut digugu lan ditiru (didengar dan dicontoh), dipertaruhkan. Karena guru adalah ujung tombak di kelas, yang berhadapan langsung dengan peserta didik.

Kegagalan guru dalam menumbuhkan karakter anak didiknya, disebabkan seorang guru yang tak mampu memperlihatkan dan menujukkan karakter sebagai seorang yang patut didengar dan diikuti. Sebagai seorang guru tidak hanya sekedar menyampaikan materi ajar kepada siswa. Namun, yang lebih mendasar dan mutlak adalah bagaimana seorang guru dapat menjadi inspirasi dan suri tauladan yang dapat merubah karakter anak didiknya-menjadi manusia yang mengenal potensi dan karakternya sebagai makhluk Tuhan dan sosial.

Pembentukan karakter merupakan salah satu tujuan pendidikan nasional. Pasal I UU Sisdiknas tahun 2003 menyatakan bahwa di antara tujuan pendidikan nasional adalah mengembangkan potensi peserta didik untuk memiliki kecerdasan, kepribadian, dan akhlak mulia. Amanah undang-undang tersebut dimaksudkan agar pendidikan tidak hanya membentuk insan Indonesia yang cerdas, namun juga berkepribadian atau berkarakter, sehingga nantinya akan lahir generasi bangsa yang tumbuh berkembang dengan karakter yang bernafas nilai-nilai luhur bangsa serta agama. 
Pendidikan adalah suatu proses inkulturasi, berfungsi mewariskan nilai-nilai dan prestasi masa lalu ke generasi mendatang. Nilai-nilai dan prestasi itu merupakan kebanggaan bangsa dan menjadikan bangsa itu dikenal oleh bangsa-bangsa lain. Selain mewariskan, pendidikan juga memiliki fungsi untuk mengembangkan nilai-nilai budaya dan prestasi masa lalu itu menjadi nilai-nilai budaya bangsa yang sesuai dengan kehidupan masa kini dan masa yang akan datang, serta mengembangkan prestasi baru mencerminkan budaya dan karakter bangsa; yang menjadi karakter baru bangsa. Oleh karena itu, pendidikan budaya dan karakter bangsa merupakan inti dari suatu proses pendidikan.

Nilai-nilai yang dikembangkan dalam pendidikan karakter dan budaya bangsa diidentifikasidariAgama,Pancasila,Budaya,dan Tujuan Pendidikan Nasional. Hanya terdapat delapan belas karakter yang mencoba untuk ditanamkan dalam materi tersebut. Sementara madrasah mempunyai corak keagamaan yang lebih kental yang mempunyai basis pendidikan akhlak tersendiri yang mengatur manusia dari bangun tidur hingga tidur lagi. Akhlak dalam Islam diteladankan oleh Rasulallah Saw (QS Al Ahzab: 21)., juga disebutkan dalam suatu hadits; " Sesungguhnya aku diutus di dunia ini tak lain untuk menyempurnakan akhlak budi pekerti yang baik" (HR.Ahmad).

Pendidikan karakter merupakan tanggung jawab semua pihak ataupun lembaga, baik orang tua, masyarakat maupun sekolah/madrasah. Salah satu sekolah/madrasah sebagai pondasi awal pendidikan karakter anak adalah sekolah tingkat dasar (SD/MI). Madrasah Ibtidaiyah (MI) merupakan jenjang pendidikan dasar dalam tingkatan pendidikan di madrasah formal, di dalamnya terdapat anak-anak yang berusia emas (golden age) yang mampu merekam pesan pendidikan dengan baik dan belum banyak terkontaminasi oleh informasiinformasi negatif.

Untuk itu penting kiranya dilakukan penelitian terkait dengan pembentukan karakter anak di madrasah, terutama di Madrasah Ibtidaiyah sebagai tonggak pendidikan lebih lanjut. Tujuan penelitan untuk mengetahui: 1) Pandangan dan kebijakan pimpinan tentang pendidikan karaker di Madrasah Ibtidaiyah, 2) Pelaksanaan pembentukan karakter di Madrasah Ibtidaiyah, dan 3) Evaluasi/penilaian pembentukan karakter di Madrasah Ibtidaiyah

\section{Kerangka Berpikir}

Pendidikan adalah usaha sadar dan terencana untuk mewujudkan suasana belajar dan proses pembelajaran agar peserta didik secara aktif mengembangkan potensi dirinya untuk memiliki kekuatan spiritual keagamaan, pengendalian diri, kepribadian, kecerdasan, akhlak mulia, serta keterampilan yang diperlukan dirinya, masyarakat, bangsa dan negara.

Banyak sekali para konsep Karakter sebagaimana dikutip oleh Tim Peneliti Balai Penelitian dan Pengembangan Agama Jakarta ${ }^{1}$. Salah satunya definisi yang dikemukakan oleh Ryan dan Bohlin, karakter mengandung tiga unsur, yaiu; mengetahui kebaikan (knowing the good), mencintai kebaikan (loving the good) dan melakukan kebaikan (doing the good). Karakter adalah watak, sifat atau hal-hal yang memang sangat mendasar yang ada pada diri seseorang. Terdapat persamaan antara pendidikan karakter, moral, akhlak dan budi pekerti. Sekalipun mempunyai persamaan namun mempunyai akar yang berbeda. Sejalan dengan pendapat tersebut, Dirjen Pendidikan Agama Islam, Kementerian Agama Republik Indonesia, mengemukakanbahwakarakter dapat diartikan sebagai totalitas cirri-ciri pribadi yang melekat dan dapat didefinisikan pada perilaku individu yang bersifat unik. Dalam arti secara khusus cirri-ciri ini membedakan antara satu individu dengan yang lainnya. Dengan demikian, istilah karakter berkaitan erat dengan personality (kepribadian) seseorang, sehingga ia disebut

1 Tim Peneliti Balai Litbang Agama Jakarta, "Pendidikan Karakter di Madrasah", Jakarta: 2013: 8 - 9. 
orang yang berkarakter jika perilakunya sesuai dengan etika atau kaidah normal.

Definisi lainnya adalah dari Suyanto dalam Masnur, yang menyatakan bahwa karakter adalah cara berpikir dan berperilaku seseorang yang menjadi cirri khas dari tiap individu untuk hidup dan bekrja sama, baik dalam lingkup keluarga, masyarakat, bangsa dan negara. ${ }^{2}$ Pendapat lain adalah dari Hermawan Kertajaya, bahwa karakter merupakan ciri khas yang dimiliki oleh suatu benda atau individu. Ciri khas tersebut adalah asli dan mengakar pada kepribadian individu tersebut dan merupakan mesin pendorong bagaiman seorang bertindak, berujar dan merespon sesuatu. $^{3}$

Menurut Doni Koesoma, karakter disoaialiasikan dengan temperamen yang memberinya sebuah definisi dengan pendidikan dan konteks lingkungan. Karakter juga dipahami dari sudut pandang behavioral yang menekankan unsure somatopsikis yang dimiliki individu sejak lahir. Di sini, karakter dianggap sebagai cirri atau karakteristik atau gaya/ sifat khas dri diri seseorang, yang bersumber dri bentukan-bentukan yang diterima dari lingkungan, misalnya pengaruh keluarga pada masa kecil dan bawaan seseorang sejak lahir. ${ }^{4}$

Untuk membentuk karakter anak bukan hanya menjadi tanggung jawab guru agama, melainkan semua tenaga pendidik dan kependidikan bertanggung jawab terhadap proses pembentukan tersebut. Pendidik harus secara terpadu mengelola pembelajaran menuju pembentukan karakter anak, di antaranya dengan keterpaduan kurikulum pada tiap-tiap mata pelajaran.

${ }^{2}$ Muslich Masnur, 'Pendidikan Karakter Menjawab Tantangan Kritis Myltidimensional', Jakarta: Bumi Aksara, 2011: h. 70.

${ }^{3}$ Hermawan Kertajaya, 'Grow With Carracter; The Model Marketting', Jakarta: PT.Gramedia Pustaka Utama, 2010: h. 3.

${ }^{4}$ Doni Kusuma A, 'Pendidikan Karakter; Strategi Mendidik Anak di Zaman Modern', Jakarta: PT.Grasindo: 2007.
Dalam keterpaduan kurikulum (Integreted Curiculum), pelajaran dipusatkan pada suatu masalah atau topik tertentu. Apa yang disajikan di sekolah, disesuaikan dengan kekhidupan anak di luar sekolah Pengintegrasian pembelajaran di kelas harus didukung dengan pembiasaan di sekolah, kegiatan ekstra kurikuler dan aplikasi keseharian di rumah masingmasing untuk membentuk karakter yang baik.

\section{Metodologi Penelitian}

Jenis Penelitian ini merupakan penelitian kualitatif deskriptif. Sesuai dengan jenis penelitian tersebut, maka metode pengumpulan data yang digunakan adalah dengan wawancara mendalam (indepth interview), Focus Group Discussion (FGD), observasi dan dokumentasi. Wawancara ditujukan kepada pimpinan yayasan, pimpinan pondok pesantren, pimpinan madrasah, guru dan juga beberapa siswa, yang dimaksudkan untuk memperoleh data tentang: 1) Profil sasaran lembaga, 2) Pandangan Pimpinan Tentang Pendidikan Karakter, 3) Penerapan Pendidikan di MI, dan 4) Kendala yang dihadapi. FGD dilakukan untuk mendiskusikan berbagai persoalan dan solusi terkait topik penelitian. Observasi untuk mengamati objek penelitian khususnya yang berkaitan dengan proses pembentukan karakter anak di Madrasah Ibtidaiyah Modern Sahid serta sarana dan prasarana yang mendukung proses pembelajaran. Dokumentasi dimaksudkan untuk memperoleh data pendukung yang berbentuk dokumen, baik yang berupa: buku, brosur, syllabus, RPP maupun CD, dsb.

Data yang telah diperoleh kemudian dikelompokkan menjadi beberapa kategori, diolah dan direduksi serta disajikan secara deskriptif dalam bentuk tulisan kualitatif. Lokasi penelitian adalah di Kabupaten Bogor, Propinsi Jawa Barat. Pertimbangan penentuan propinsi tersebut didasari bahwa Jawa Barat sebagai provinsi terdekat dengan Jakarta dimungkinkan akan memperoleh dampak lebih 
cepat dibanding dengan provinsi lainnya. Sasaran Penelitian adalah Madrasah Ibtidaiyah Modern Sahid. Alasan pemilihan MI tersebut didasari pada pertimbangan, bahwa: 1) MI Sahid Modern merupakan madrasah swasta yang berada dalam lingkungan pondok pesantren, dan 2) Sebagai sekolah unggulan di Kaupaten Bogor. Sehingga diharapkan hasil penelitian ini dapat menjadi contoh ataupun model bagi madrasah lain dalam penyelenggaraan pendidikan, teruatama dalam pembentukan karakter. Penentuan Madrasah Ibtidaiyah sebagai sasaran penelitian dengan pertimbangan, bahwa MI merupakan jenjang pendidikan formal paling dasar yang di dalamnya masih terdapat usia anak-anak (golden age). Yang lebih mudah untuk diarahkan pada pembentukan karakter yang lebih baik.

\section{HASIL DAN PEMBAHASAN}

\section{Sekilas MIS Modern Sahid Bogor}

\section{Sejarah Singkat}

Pendidikan dasar sangat penting karena menjadilandasan untuk melanjutkan kejenjang pendidikan selanjutnya dan menjadi modal utama untuk berkembang secara otodidak bagi yang tidak mampu atau tidak mau melanjutkan program di sekolah formal. Namun, untuk menyukseskan program tersebut, pemerintah tidak dapat melaksanakannya sehingga, sehingga semua warga Negara harus ikut bertanggung jawab terhadap penyelenggaraan pendidikan tersebut. Oleh karena itu, Pondok Pesantren Modern Sahid mengembangkan Madrasah Ibtidaiyah (MI) Modern Sahid sesuai tuntutan perkembangan zaman, sebagai wujud partisipasi dalam memajukan pendidikan Islam untuk masyarakat sekitar.

Akhirnya pada tahun pelajaran 2009/2010 Pondok Pesantren Modern Sahid resmi mewujudkan partisipasinya di bidang pendidikan Madrasah Ibtidaiyyah (MI), yaitu salah satu bentuk dasar yang memberi penekanan pada pendidikan agama Islam lebih banyak dibanding Sekolah Dasar biasa. Setelah mendapatkan ijin operasional dari Kantor Departemen Agama kabupaten Bogor yang diberikan sebagai hadiah ulang tahun pesantren ke-8 (satu windu), MI Modern Sahid membuka pendaftaran dan memulai kegiatannya dengan jumlah siswa 48 anak yang diasuh oleh empat orang guru dan satu orang kepala sekolah yaitu Ibu Siti Zahroh, S.Ag. Sejak berdiri MI Modern Sahid telah dirancang menjadi Madrasah bertaraf internasional yang dibimbing oleh seorang konsultan berpengalaman di bidangnya yaitu Ibu Dra.Inti Farhati, MA.

\section{Landasan Pendirian}

Landasan pendirian MIS Modern Sahid Bogor meliputi: 1) Amanah UUD 1945 "Mencerdaskan kehidupan bangsa.", 2) Program Pemerintah "Wajib belajar sembilan tahun.", 3) UU RI No.20 Th. 2003 (UU Sisdiknas) Pasal 6 ayat 1:"Setiap warga Negara yang berusia tujuh sampai lima belas tahun wajib mengikuti pendidikan dasar"., 4) UU RI No.20 Th. 2003 (UU Sisdiknas) Pasal 17 ayat 2 yang memberi penekanan bahwa pendidikan Agama Islam pada Madrasah Ibtidaiyah lebih banyak di banding Sekolah Dasar biasa., 5) Pendidikan agama dan pendidikan umum harus diintegrasikan menjadi satu agar dapat mencapai kesejahteraan lahir dan batin dunia akhirat, 5) Al Qur'an surat Al-Mujadilah ayat 11: "Allah akan meninggikan orang-orang yang beriman di antaramu dan orang-orang yang diberi ilmu pengetahuan beberapa derajat", dan 6) Al Hadits: "Barang siapa yang menghendaki dunia maka dengan ilmu dan barang siapa yang menghendaki akhirat maka dengan ilmu dan barang siapa yang menghendaki keduanya maka dengan ilmu".

\section{Tujuan Pendirian}

PendirianMIbertujuanuntuk:1)Membantu orang tua dalam memberikan kemampuan dasar kepada anak agar dapat mengembangkan 
potensinya dan dapat melanjutkan ke jenjang pendidikan berikutnya, 2) Memberikan kontribusi terhadap peningkatan kualitas pendidikan dasar yang modern dan islami khususnya pada jenis pendidikan Madrasah, dan 3) Berpartisipasi aktif dalam pelaksanaan wajib belajar sembilan tahun.

\section{Visi dan Misi}

MIS Modern Sahid dengan No. Statistik Masrasah: 111232010272 berlokasi di Jl. KH. Abdul Hamid KM.6 Gunung Menyan, Kecamatan Pamijahan, Kabupaten Bogor, Propinsi Jawa Barat, dengan visi yang dicanangkan adalah: "Menjadikan Madrasah Ibtidaiyah Modern Sahid sebagai Sekolah Dasar Islam. Untuk mewujudkan visi tersebut, maka misi yang dikembangkan adalah: 1) Menghasilkan anak yang sholeh, sehat, kreatf dan memiliki
S.Pd.SD sebagai Kepala Sekolah. Sedangkan tenaga pendidik yang dimiliki sejumlah 5 (lima) orang (2 orang laki-laki dan 3 orang perempuan), dan dibantu oleh 2 (dua) tenaga non kependidikan. Tenaga pendidik semuanya berpendidikan perguruan tinggi (sarjana) dengan ragam disiplin ilmu, sementara tenaga non kependidikan (staf administrasi) latar belakang pendidikannya adalah SMA dan SMP.

Semua tenaga pendidik pernah dan sering mengikuti kegiatan peningkatan dan pengembangan kompetensi untuk menunjang pekerjaannya. Seperti: Penataran Kurikulum, Penataran Metode Pembelajaran, Penataran PTK, Penataran karya Tulis Ilmiah, dan Sertifikasi Profesi/Kompetensi.

Tabel: 1

Data Siswa 3 (Tiga) Tahun Terakhir MIS Modern Sahid Bogor

\begin{tabular}{|c|c|c|c|c|c|c|c|c|c|c|c|c|c|c|c|}
\hline \multirow{2}{*}{$\begin{array}{c}\text { Tahun } \\
\text { Pelajaran }\end{array}$} & \multirow{2}{*}{$\begin{array}{c}\text { Jml } \\
\text { Pendaftar } \\
\text { (Cln Siswa } \\
\text { Baru) }\end{array}$} & \multicolumn{2}{|c|}{ Kelas I } & \multicolumn{2}{|c|}{ Kelas II } & \multicolumn{2}{|c|}{ Kelas III } & \multicolumn{2}{|c|}{ Kelas IV } & \multicolumn{2}{|c|}{ Kelas V } & \multicolumn{2}{|c|}{ Kelas VI } & \multicolumn{2}{|c|}{$\begin{array}{c}\text { Jumlah } \\
\text { (KIs. I+VI) }\end{array}$} \\
\hline & & $\begin{array}{l}\text { Jml } \\
\text { Siswa }\end{array}$ & \begin{tabular}{|l} 
Jumlah \\
Rombel
\end{tabular} & $\begin{array}{l}\text { Jml } \\
\text { Siswa }\end{array}$ & \begin{tabular}{|l} 
Jumlah \\
Rombel
\end{tabular} & $\begin{array}{l}\text { Jml } \\
\text { Siswa }\end{array}$ & \begin{tabular}{|l} 
Jumlah \\
Rombel
\end{tabular} & $\begin{array}{l}\text { Jml } \\
\text { Siswa }\end{array}$ & $\begin{array}{l}\text { Jumlah } \\
\text { Rombel }\end{array}$ & $\begin{array}{l}\text { Jml } \\
\text { Siswa }\end{array}$ & $\begin{array}{c}\text { Jml } \\
\text { Rombel }\end{array}$ & $\begin{array}{c}\text { Jml } \\
\text { Siswa }\end{array}$ & $\begin{array}{l}\text { Jumlah } \\
\text { Rombel }\end{array}$ & Siswa & Rombel \\
\hline $2009 / 2010$ & 15 & 13 & 1 & & & & & & & & & & & 13 & 1 \\
\hline $2010 / 2011$ & 10 & 10 & 1 & 13 & 1 & & & & & & & & & 23 & 2 \\
\hline $2011 / 2012$ & 15 & 12 & 1 & 9 & 1 & 13 & 1 & & & & & & & 34 & 3 \\
\hline $2012 / 2013$ & 27 & 25 & 2 & 13 & 1 & 9 & 1 & 14 & 1 & & & & & 61 & 5 \\
\hline
\end{tabular}

kemampuan akademik serta keterampilan dasar sesuai dengan standar kompetensi yang ditetapkan Pemerintah maupun ketentuan dan aturan yang berlaku, 2) Mengembangkan seluruh potensi yang dimiliki anak sesuai dengan tahap perkembangan sehingga madrasah berfungsi sebagai central of learning dalam mengaplikasikan IMTAQ dan IPTEK, dan 3) Mengadakan pembinaan tenaga pendidik, sehingga menjadi kader bangsa yang mumpuni dalam aspek kepribadian, keilmuan dan skill keguruan.

\section{Sumber Daya Manusia}

Pada tahun pelajaran 2012/2013, MIS Modern Sahid dipimpin oleh Doni Rahman,

\section{Sarana Prasarana}

Status tanah adalah milik Yayasan Sahid Husnul Khatimah sebagai hak milik, luas keseluruhan $2800 \mathrm{~m} 2$, dengan luas bangunan $1500 \mathrm{~m} 2$ dan tanah siap bangun $1300 \mathrm{~m} 2$. Fasilitas yang ada cukup memadai untuk belajar, di antaranya adalah: 1) Ruang kelas yang lengkap dan menyenangkan sesuai standar, 2) Gedung yang terdiri dari beberapa ruang untuk kantor guru, Kepala MI, tata usaha, ruang tamu, ruang kesehatan, pantry dan gudang, 3) Arena berolah raga dan bermain yang nyaman, 4) Mobil antar jemput, 5) Ruang tunggu orang tua/pengantar, dan 6) Ruang dinas untuk Kepala MI 


\section{Kegiatan Pembelajaran}

\section{Struktur Kurikulum dan Alokasi Waktu}

Struktur kurikulum adalah pola dan susunan mata pelajaran yang harus ditempuh oleh peserta didik pada satuan pendidikan dalam kegiatan belajar, dengan kelompok mata pelajaran sebagai berikut: 1) Agama dan akhlak mulia, 2)Kewarganegaraan dan kepribadian, 3) Ilmu pengetahuan dan teknologi, 4) Estetika, dan 5) Jasmani, olahraga dan kesehatan.

Struktur kurikulum MI Modern Sahid meliputi substansi pembelajaran yang ditempuh dalam satu jenjang pendidikan selama 6 (enam) tahun, mulai dari kelas I sampai dengan kelas VI, yang disusun berdasarkan standar kompetensi lulusan dan standar kompetensi mata pelajaran dengan ketentuan sebagai berikut:

1. Kurikulum kelas I s/d VI MI Modern Sahid meliputi 12 mata pelajaran,3 muatan lokal, 5 pengembangan diri.

2. Substansi mata pelajaran IPA dan IPS merupakan "IPA terpadu dan IPS terpadu".

3. Pembelajaran pada kelas I s/d III dilaksanakan melalui pendekatan TEMATIK, sedangkan pada kelas IV s/d kelas VI dilaksanakan melalui pendekatan mata pelajaran.

4. Alokasi waktu satu jam pelajaran adalah 35 menit.

5. Minggu efektif dalam satu tahun pelajaran (2 semester) adalah 36 minggu.

\section{Mata Pelajaran}

Mata pelajaran di MID Modern Sahid terdiri dari:

1. Mata Pelajaran Inti, yang meliputi: AlQur'an Hadits, Aqidah Akhlak, Fiqih, Sejarah, Kebudayaan Islam, Bahasa Arab, Pendidikan Kewarganegaraan, Bahasa Indonesia, Matematika, IPA, IPS, Seni
Budaya dan Keterampilan, dan Penjas Orkes .

2. Muatan Lokal, meliputi: Bahasa Inggris, Bahasa Sunda, dan TIK

3. Pengembangan diri, meliputi: Pramuka, Gamelan, Futsal, Lukis, dan Tari

4. Pembiasaan, meliputi: Upacara bendera, Sholat Dhuha dan Dhuhur, Baca tulis al Qur'an, dan Tahfidz al Qur'an.

\section{Standar Kompetensi Lulusan}

1. Menguasai standar kompetensi yang ditetapkan pemerintah dengan indikator lulus Ujian Madrasah dengan baik

2. Menguasai Bahasa Arab tingkat dasar dengan baik, dengan indikator: 1) dapat berkomunikasi secara lisan dengan fasih dan lancar, 2) dapat menulis kalimat sederhana dengan baik dan benar, dan 3) dapat membaca dan memahami artikel Bahasa Arab sederhana dengan baik.

3. Menguasai Bahasa Inggris tingkat dasar dengan baik, dengan indikator: 1) dapat berkomunikasi secara lisan dengan fasih dan lancar, 2) dapat menulis kalimat sederhana dengan baik dan benar, dan 3) dapat membaca dan memahami artikel Bahasa Inggris sederhana dengan baik.

4. Taat menjalankan ibadah fardhu dan rajin menjalankan ibadah sunnah.

5. Selalu berakhlak mulia terhadap diri sendiri, orang lain dan lingkungan.

6. Dapat membaca Al Qur'an dengan fasih dan lancar serta hafal minimal Juz'amma dan beberapa ayat pilihan serta do'a-do'a harian.

7. Dapat mengoperasikan komputer dan internet dengan baik.

8. Menguasai minimal dua cabang olahraga dan dua cabang kesenian dengan baik 


\section{Kegiatan Pembiasaan dan Ekstrakurikuler}

Kegiatan pembiasaan merupakan kegiatn rutin yang wajib diikuti oleh semua siswa, yang meliputi: 1) Upacara Bendera; dilaksanakan setiap hari Senin dan setiap hari besar nasional yang wajib diikuti oleh semua siswa, 2) Shalat Dhuha dan Dzuhur berjamaah setiap hari, 3) BTQ; setiap hari, dan 4) Tahfizh Al-Quran; setiap hari.

Kegiatan ekstrakurikuler sebagai kegiatan pengembangan diri yang wajib diikuti oleh semua siswa, yang meliputi: musik gamelan, Pramuka, futsal, seni tari, melukis, pengembangan dari SBK, Komputer (pengembangan dari TIK), dan drum band (mulai Juli 2012)

\section{Penilaian}

Dalam setiap proses pembelajaran tentunya harus dilihat hasilnya, baik ketika proses (formatif) maupun selesai proses pembelajaran (sumatif). Aspek penilaian ketika proses pembelajaran berlangsung tidak hanya terbatas pada materi yang diajarkan (kognitif), tetapi juga ditekankan pada penilaian perkembangan akhlak siswa.

Alat penilaian proses pembelajaran yang digunakan berupa pertanyaan lisan, pengamatan dan lembar kerja siswa (work sheet. Lembar tersebut memuat tugas individu maupun kelompok, baik ketika di sekolah maupun di luar sekolah.

Sebagaimana sekolah pada umumnya, penilaian setelah selesai proses pembelajaran (sumatif) dilakukan setiap akhir semester dilakukan 2 (dua) kali dalam 1 (satu) semester. Dalam pertengahan semester bentuk penilaian berupa Laporan Perkembangan Anak, yang memuat uraian kemampuan (kompetensi) siswa dari setiap mata pelajaran. Sementara bentuk penilaian akhir semester berupa Raport Hasil Belajar.

Uraian penilaian pertengahan semester yang tertuang dalam Laporan Perkembangan Anak berupa narasi tingkat kemampuan masing-masing siswa dalam penguasaan setiap materi pelajaran, dengan indikator "mampu" menguasai (menjelaskan, mengidentifikasi, mengenal, menyebutkan, menghafal, dsb.). Dalam Laporan Perkembangan Anak tersebut, berisi juga kondisi ataupun sikap siswa dalam pembelajaran dan saran-saran untuk perkembangan anak selanjutnya.

Sedangkan uraian penilaian akhir semester yang berbentuk Raport berisi hasil prestasi siswa dalam setiap mata pelajaran yang berupa angka, dengan indikator pencapaian kriteria ketuntasan minimal "KKM" (di bawah, sama atau di melampaui KKM).. .

\section{Pandangan dan Kebijakan Pimpinan Tentang Pendidikan Karakter}

Menurut pimpinan harian Pondok pesantren Modern Sahid Bogor, bahwa pembentukan karakter yang salah satu sumber utamanya adalah agama merupakan bagian tak terpisahkan dalam proses pendidikan, baik di sekolah, di rumah maupun di masyarakat. Sebenarnya dalam agama Islam sudah ada istilah yang lebih komprehensif dan universal dibanding karakter yaitu ahlakul karimah (akhlak mulia). Oleh karena itu, membahas masalah pendidikan karakter di lingkungan pendidikan seperti madrasah, apalagi di lingkungan pondok pesantren merupakan sesuatu yang tidak biaa dipisahkan, keduanya merupakan simbiosis dan melekat dalam proses pembelajaran sehari-hari (Drs.KH. Ahmad Sadjid Zain, MM, 5 November 2012).

Pendidikan karakter atau ahlak mulia melalui sekolah merupakan usaha mulia yang terus ditekankan dan dikembangkan. Kalau kita berbicara tentang masa depan, sekolah tidak hanya bertanggungjawab dalam mencetak peserta didik yang unggul dalam ilmu pengetahuan dan teknologi, tetapi yang lebih penting adalah pembentukan jati diri, karakter dan kepribadian yang Islami. Hal ini sesuai dengan visi yang dicanangkan oleh pondok pesantren Modern Sahid (Drs. H.Ade 
Hasanudin, Kepala Bidang Humas: 5 November 2012).

Begitu pentingnya pembentukan ahlakul karimah bagi anak, maka di semua lembaga pendidikan di lingkungan Pondok Pesangtren Modern Sahid, selalu dikondisikan lingkungan sebagai berikut:

1. Penerapan pendekatan "modelling" atau "exemplary" atau "uswah hasanah ("modelling"). Yakni membiasakan dan mensosialisasikan lingkungan sekolah untuk mengembangkan dan menegakkan nilainilai akhlak mulia melalui teladan. Semua unsur pondok, baik pimpinan, tenaga pendidik (ustadz/ustadah), wali asrama (murobbi/murabbiyah) dan tenaga kependidikan lain di lingkungan sekolah/pondok selalu berusaha untuk mampu menjadi "uswah hasanah" yang hidup (living exemplary) bagi setiap peserta didik (santri). Mereka juga selalu terbuka dan siap untuk mendiskusikan dengan peserta didik tentang berbagai nilai-nilai yang baik.

2. Menjelaskan atau mengklarifikasikan kepada peserta didik secara terus menerus tentang berbagai nilai yang baik dan yang buruk. Usaha ini dilakukan pada setiap kegiatan dan momen, baik di kelas, di asrama maupun dalam kehidupan seharihari. 1) Di kelas, diwajibkan membaca do'a sebelum dan sesudah pelajaran, 2) Di setiap Rencana Pelaksanaan Pembelajaran (RPP) selalu ditekankan adanya nilai-nilai pendidikan karakter yang diharapkan dari masing-masing pokok bahasan; 3) Mengucap basmallah sebelum memulai pekerjaan, 4) Di asrama/pondok, sikap dan perilaku siswa/santri selalu di bawah bimbingan dan pengawasan murobbi/ murobbiyah (1 ruang yang terdiri dari 30 siswa dipimpin oleh 1 orang muroobi/ murobbiyah); 5) Dalam kehidupan seharihari pengawasan juga menjadi tanggung jawab guru, santri senior dan juga orang tua. Usaha ini dibarengi pula dengan langkah- langkah memberi penghargaan (prizing) dan menumbuhsuburkan (cherising) nilainilai yang baik dan sebaliknya mencegah (discouraging) berlakunya nilai-nilai yang buruk dan memberi sangsi bagi yang melanggar dengan cara memberi surat peringatan, ataupun bahkan bisa dikembalikan kepada orang tuanya.

3. Menegaskan nilai-nilai yang baik dan buruk secara terbuka dan kontinu; usaha ini dilakukan dalam setiap saat kegiatan maupun dalam pergaulan sehari-hari antar unsure pondok, baik ketika bergaul dengan pimpinan, pondok, tenaga pendidik dan kependidikan dan sesame teman siswa.

4. Memberikan kesempatan kepada peserta didik untuk memilih berbagai alternatif sikap dan tindakan berdasarkan nilai; melakukan pilihan secara bebas setelah menimbang dalam-dalam berbagai konsekuensi dari setiap pilihan dan tindakan; membiasakan bersikap dan bertindak atas niat dan prasangka baik (husn al-zhan) dan tujuan-tujuan ideal; membiasakan bersikap dan bertindak dengan pola-pola yang baik yang diulangi secara terus menerus dan konsisten.

5. Penerapan pendidikan berdasarkan karakter (character-based education). Hal ini dilakukan dengan menerapkan characterbased approach ke dalam setiap mata pelajaran nilai yang ada di samping mata pelajaran-mata pelajaran khusus untuk pendidikan karakter, seperti pelajaran agama, pendidikan kewarganegaraan (PKn), sejarah, Pancasila dan sebagainya. Dalam pembelajarannya, tidak hanya bersifat verbalisme dan sekedar hapalan, tetapi betul-betul diupayakan untuk membantu pembentukan ahlak mulia dan juga karakter.bangsa. 


\section{Penerapan Pendidikan Karakter}

Tahapan penerapan pendidikan karakter meliputi perencanaan, pelaksanaan dan penelilaian. Berikut penjelasan dari masingmasing tahapan tersebut.

1. Perencanaan pendidikan karakter, meliputi berbagai strategi. Pertama; yaitu: mengintergrasikan ke dalam setiap mata pelajaran, bertujuan untuk memperkenalkan nilai-nilai pendidikan karakter di setiap mata pelajaran sehingga siswa manyadari akan pentingnya nilainilai tersebut. Kedua; Mengintergrasikan ke dalam mata pelajaran muatan lokal bertujuan untuk mengembangkan kompetensi yang ada. Ketiga; Melalui kegiatan pengembangan diri dapat dilakukan dengan cara kegiatan ekstrakulikuler, pembiasaan dan nasionalisme. Kelima; Pengkondisian, baik secara fisik maupun non fisik.

2. Pelaksanaan Pendidikan Karakter

Pelaksanaan atau penerapan pendidikan karakter diMIS Modern Sahid dilakukan pada kegiatan pembelajaran, pengembangan budaya sekolah dan pusat kegiatan belajar, kegiatan ko-kurikuler dan atau kegiatan ekstrakurikuler, dan kegiatan keseharian di rumah dan di masyarakat.

Kegiatan pembelajaran; penerapan pendidikan karakter pada pelaksanaan pembelajaran dimulai dari penyususunan Rencana Pelaksanaan Pembelajaran (RPP). Dalam setiap penilaian, selalu dimunculkan secara eksplisit indikator ataupun kriteria nilai budaya dan karakter yang diharapkan. Berikut beberapa contoh RPP yang penilaiannya memunculkan nilai budaya dan karakter:

Kelas I, mata pelajaran Bahasa Inggris dan materi pengenalan buah (Listening, Speaking, Reading dan Writing). Nilai karakter yang diharapkan dari pelajaran ini adalah: kerja keras, mandiri, gemar membaca, bersahabat/komunikatif dan tanggung jawab.

Kelas II, mata pelajaran Fiqh, dan materi pelajaran Adzan dan Iqomah. Nilai karakter yang diharapkan adalah: religious, jujur, toleransi, disiplin, kerja keras, kreatif, demokratif, rasa ingin tahu, gemar membaca dan peduli.

Kelas III, mata pelajaran Ilmu Pengetahuan Alam (IPA), dan materinya adalah "Benda dan kegunaannya". Nilai karakter yang diharapkan: disiplin, ketelitian, ketekunan, percaya diri dan tanggung jawab.

Kelas IV, mata pelajaran Pendidikan Kewarganegaraan, dengan materi sistem pemerintahan kabupaten, kota dan propinsi". Karakter siswa yang diharapkan meliputi: 1) dapat dipercaya, 2) rasa hormat dan perhatian, 4) tekun, 5) tanggung jawab, 6) berani, 7) integritas, 8) jujur, dan 9) kewarganegaraan.

Namun demikian, ada beberapa indikator nilai-nilai karakter yang dimunculkan kurang sesuai dengan materi yang diajarkan. Misal, materi hafalan surat pendek, tetapi nilai-nilai karakter yang ditetapkan adalah: peduli social dan demokratif. Menurut Kepala Madrasah, memang sering ditemukan beberapa indikator nilai karakter kurang sesuai dengan materi yang diajarkan, disebabkan karena kurang ketelitian dari guru yang bersangkutan.

Dalam pelaksanaannya dengan menggunakan pendekatan kontekstual, yaitu siswa diajak menghubungkan atau mengkaitkan materi yang dipelajari dengan dunia nyata, dan akhirnya diharapkan bahwa pengetahuan yang dimiliki dapat diterapkan dalam kehidupan sehari-hari. Dengan pendekatan tersebut, siswa lebih memiliki hasil yang komprehensif tidak hanya pada tataran kognitif (olah pikir), tetapi pada tataran afektif (olah hati, rasa dan karsa), serta psikomotor (olah raga) (Puskur, 2011: 8). Lebih dari itu, dengan strategi yang tepat diharapkan dapat mengembangkan dan 
membentuk karakter siswa yang optimal, seperti: cerdas, berpikir terbuka, tanggung jawab dan rasa ingin tahu.

\section{Pengembangan Budaya Sekolah dan Pusat Kegiatan Belajar}

Pengembangan budaya sekolah dan pusat kegiatan belajar dilakukan melalui kegiatan pengembangan diri, yaitu kegiatan rutin, spontan, keteladanan dan pengkondisian.

Kegiatan rutin; sebagai bentuk kegiatan pembiasaan pendidikan karakter merupakan kegiatan yang ajeg dilakukan setiap saat. Beberapa contoh kegiatan yang telah diterapkan antara lain: 1) kegiatan upacara hari Senin, 2) upacara besar kenegaraan, 3) pemeriksaan kebersihan badan, 4) piket kelas, 5) sholat berjamaah, 6) sholat Dhuha, 7) berbaris ketika masuk kelas,8) berdoa sebelum dan setelah pelajaran, 9) mengucapkan salam apabila bertemu guru, tenaga pendidik dan teman, 10) baca Tulis Al Qur'an (BTQ) dan 11) berkurban pada hari raya Idul Adha

Kegiatan spontan; dilakukan secara spontan tanpa perencanaan terlebih dahulu. Seperti: mengumpulkan sumbangan ketika ada teman yang terkena musibah atau sumbangan untuk masyarakat ketika terjadi bencana, berkunjung kepada sesama teman ataupun guru yang sakit atau tertimpa musibah.

Keteladanan; merupakan sikap dan perilaku dari semua unusur lembaga/pondok (pimpinan, guru dan tenaga non kependidikan) dalam memberikan contoh melalui tindakantindakan yang baik, sehingga diharapkan menjadi panutan bagi siswa. Oleh karena itu, sangat ditekankan bagi semua unsur di pondok pesantren dan madrasah untuk selalu bersikap dan bertindak sesuai dengan nilainilai agama dan norma yang berlaku. Karena semua sikap dan perilaku mereka akan dilihat, diperhatikan, dinilai, dan akhirnya bisa juga diikuti/ditiru oleh anak/siswa. Tauladan yang dimaksud, misalnya: pribadi yang bersih, rapi, ramah, taat beribadah, jujur, suka menolong, tanggung jawab, disiplin, sopan, kreatif, mandiri, menghargai perbedaan (toleran), menghargai prestasi seseorang, senang membaca, dan supel atau komunikatif (mudah bergaul). Dengan keteladanan akan memberikan pengaruh yang efektif dalam membentuk ahlak mulia anak, karena tidak ada unsur keterpaksaan, doktrinasi ataupun pendiktean.

Pengkondisian; berkaitan dengan upaya sekolah untuk menata lingkungan fisik maupun non fisik demi terciptanya suasana mendukung terlaksananya pendidikan karakter. Kegiatan menata lingkungan fisik, misalnya adalah: penataan ruangan yang rapi dan bersih, pemajangan gambar hasil karya anak didik, mengkondisikan tolilet bersih, penyediaan teclea"'mpat sampah, penciptaan halaman yang hijau dengan pepohonan, poster kata-kata mutiara Hadits, kata-kata bijak yang di pajang di dinding luar ataupun dalam kelas. Seperti: "Kebersihan sebagian dari iman", "Contoh perbuatan baik dan buruk", "Gambar contoh perbuatan akhlak terpuji, "Say salam before you come in", "Keep the enviroenment", "Bersih itu Sehat" " 3 K: Kerja keras, Kerja cerdas, Kerja ikhlas", "4 Musuh terbesar yang harus dijauhi: 1) Syetan, 2) Kebodohan, 3) Permusuhan, 4) Kegagalan", "Mulai saat ini, mulai yang terkecil, mulai dari diri sendiri", dan "Bersih itu indah".

Untuk menciptakan kondisi kelas yang nyaman dan tidak membosankan siswa untuk belajar, maka ruangan selain ditata secara rapi dan bersih, keindahan juga menjadi hal penting. Di samping dengan pemajangan katabijak ataupun kata-kata mutiara, juga dihiasi dengan gambar-genbar yang berkaitan dengan pelajaran, gambar dan benda-benda hasil karya anak, dan hal-hal yang menarik sesuai dengan usia anak. Pemajangan hasil karya anak akan memberikan pengaruh yang posistif bagi anak. Karena anak akan merasa dihargai kemampuannya, memotivasi siswa anak untuk selalu berkarya, mendorong kreativitas, tekun dan teliti, rasa ingin tahu, jujur dan kerja keras. 
Dalam penataan ruangan, guru mengajak para siswa untuk bersama-sama bekerja menata ruangan dalam kurun waktu tertentu. Hal ini dimaksudkan untuk memupuk dan menumbuhkembangkan rasa tanggung jawab terhadap kenyamanan lingkungan belajar.. Di samping itu, diharapkan akan tertanan nilainilai karakter positif, seperti: tanggung jawab, kerja sama, kerja keras, ketelitian, cinta bersih dan rapi, serta peduli lingkungan.

Untuk menghindari rasa jenuh, posisi tempat duduk juga ditata dengan tidak kaku dan monoton, tetapi posisi tempat duduk dibuat melingkar dan ada juga yang bias duduk di lantai, sehingga anak bebas mengekspresikan potensinya dan Nampak cukup nyamanuntuk belajar.

Pengkondisian lingkungan juga diterapkan di luar kelas, baik di lorong kelas/gedung dan juga taman.. Di dinding lorong kelas juga juga ditempel poster kata-kata bijak dan memotivasi siswa untuk menjaga lingkungan..

Pengkondisian lingkungan non fisik juga diterapkan, yaitu dengan menciptakan hubungan yang harmonis antara semua unsure di pondok, terutama antara guru dengan siswa. Hubungan yang harmonis diterapkan baik dalam proses pembelajaran di kelas, tetapi juga dalam pergaulan di luar kelas. Dengan suasana yang harmonis, siswa merasa nyaman dan merasa terlindungi, yang pada akhirnya proses pembelajaran menjadi kondusif, Di samping itu, guru juga menujukkan kesabaran dalam menghadpi siswa, selalu mengajak dan menganjurkan agar siswa untuk hidup saling tolong menolong, cinta damai, tidak sombong dan jujur dalam setiap ucapan dan perbuatan.

\section{Kegiatan Ko-Kurikuler dan atau Kegiatan Ekstrakurikuler}

Kegiatan ko-kurikuler dan ekstrakurikuler merupakan kegiatan di luar pembelajaran. Meskipun di luar kegiatan pembelajaran, guru dapat juga mengintegrasikannya dalam pembelajaran yang sangat mendukung pelaksanaan pendidikan karakter. Namun demikian tetap diperlukan perencanaan, pelaksanaan dan evaluasi yang baik atau merevitalisasi kegiatan ko-kurikuler dan ekstralurikuler, agar pelaksanaan pendidikan karakter dapat berjalan dengan baik dan kondusif.

Salah satu bentuk kegiatan ko-kurikuler adalah dengan menggunakan Buku Penghubung, yang memuat pemberitahuan dari pihak sekolah tentang berbagai hal yang berkaitan dengan kegiatan dan tugas siswa. Misal, tugas yang harus dikerjakan di rumah (PR), himbauan kepada orang tua untuk selalu membimbing putra-putrinya di rumah, pemberitahuan pertemuan orang tua dengan guru, dsb. Untuk ketertiban dan kedisiplinan administrasi, orang tua harus mencermati dan membubuhkan tanda tangan/paraf, sebagai bentuk tanggung jawab bersama antara pihak sekolah dengan orang tua.

Kegiatan ekstrakurikuler yang bertujuan untuk pengembangan diri bakat dan kompetensi siswa, juga merupakan salah satu bentuk ataupun sarana pembentukan karakter siswa. Oleh karena itu, semua siswa harus mengikuti program kegiatan ekstrakurikuler yang ada di sekolah.

Sebagaimana telah dikemukakan sebelumnya, bahwa kegiatan ekstrakurikuler di MIS Modern Sahid cukup banyak dan bervariasi. Seperti: 1) Musik Gamelan, 2) Pramuka, 3) Futsal, 4) Seni tari, 5) Melukis, 6) Komputer, dan 7) Drum band. Masing-masing kegiatan tersebut mempunyai nilai-nilai karakter sesuai dengan jenis dan karakteristik. Nilai-nilai karakter dari masing-masing jenis kegiatan tersebut dapat dilihat dari table berikut: 
Table: 2

Nilai Pendidikan Karakter Dalam Kegiatan Ekstrakurikuler

\begin{tabular}{|c|c|c|}
\hline No. & Nama Kegiatan & Nilai Karakter \\
\hline 1 & Musik Gamelan & $\begin{array}{ll}\text { 1. } & \text { Cinta budaya, tanah air } \\
\text { (nasionalisme) } \\
\text { 2. Ketelitian } \\
\text { 3. Ketekunan } \\
\text { 4. Kerja keras } \\
\text { 5. Kedisilinan } \\
\text { 6. } \\
\text { Rasa ingin tahu }\end{array}$ \\
\hline 2 & Pramuka & $\begin{array}{l}\text { 1. Religiusitas } \\
\text { 2. Kedisiplinan } \\
\text { 3. } \text { Cinta budaya, tanah air } \\
\text { (nasionalisme) } \\
\text { 4. Kemandirian } \\
\text { 5. Tanggung jawab } \\
\text { 6. Ketelitian } \\
\text { 7. Ketekunan } \\
\text { 8. Kerja keras } \\
\text { 9. Rasa ingin tahu } \\
\text { 10. Cinta damai } \\
\text { 11. Toleransi } \\
\text { 12. Tolong menolong } \\
\text { 13. Kejujuran } \\
\text { 14. Kreatif } \\
\text { 15. Peduli lingkungan } \\
\text { 16. Peduli social }\end{array}$ \\
\hline 3 & Futsal & $\begin{array}{l}\text { 1. Tanggung jawab } \\
\text { 2. Kedisiplinan } \\
\text { 3. Kejujuran } \\
\text { 4. Kerja keras } \\
\text { 5. Toleransi } \\
\text { 6. Ketekunan }\end{array}$ \\
\hline 4 & Seni tari & $\begin{array}{l}\text { 1. Cinta budaya dan tanah air } \\
\text { 2. Ketekunan } \\
\text { 3. Kerja keras } \\
\text { 4. Ketelitian } \\
\text { 5. Kedisiplinan }\end{array}$ \\
\hline 5 & Melukis & $\begin{array}{l}\text { 1. Ketekunan } \\
\text { 2. Ketelitian } \\
\text { 3. Kreatif } \\
\text { 4. Kedisiplinan }\end{array}$ \\
\hline 6 & Komputer & $\begin{array}{l}\text { 1. Ketelitian } \\
\text { 2. Ketekunan } \\
\text { 3. Rasa ingin tahu } \\
\text { 4. Kreatif } \\
\text { 5. Kedisiplinan }\end{array}$ \\
\hline
\end{tabular}

\begin{tabular}{|c|l|l|}
\hline No. & Nama Kegiatan & \multicolumn{1}{c|}{ Nilai Karakter } \\
\hline 7 & Drum band & 1. Ketekunan \\
& & 2. Kerja keras \\
& & 3. Ketelitian \\
& & 4. Kedisiplinan \\
& & 5. Toleransi \\
\hline
\end{tabular}

Kegiatan lain yang sifatnya ko-kurikuler adalah kegiatan keseharian di rumah dan di masyarakat. Kegiatan merupakan kegiatan penunjang karakter yang ada di sekolah, rumah (keluarga) dan masyarakat, sebagai partner penting suksesnya pelaksanaan pendidikan karakter di sekolah. Pendidikan karakter sebaik apapun, kalau tidak didukung oleh lingkungan keluarga dan masyarakat akan sia-sia. Dalam kegiatan ini sekolah selalu menjalin silaturahim dengan orang tua dan mengupayakan terciptanya keselarasan anatara karakter yang dikembangkan di sekolah dengan pembiasaan di rumah dan di masyarakat.

Untuk terciptanya keselarasan tanggung jawab pendidikan ahlak anak/siswa, maka pihak sekolah selalu menghimbau kepada orang tua untuk mrmbimbing putra-putrinya di rumah, baik dalam pelakanaan ibadah maupun sikap dan perilaku anak di rumah dan lingkungan masyarakat sekitar. Bentuk himbauannya melalui Buku Penghubung, pengajian rutin, melalui pertemuan-pertemuan antara orang dan guru/pimpinan, dan kegiatan-kegiatan tertentu.

\section{Penilaian}

Sebagaimana dikemukakan sebelumnya bahwa jalinan silaturahim dan keselarasan tanggung jawab antara sekolah dengah dengan orang tua sangat ditekankan, baik melalui Buku Penghubung maupun dalam kegiatankegiatan tertentu, secara tidak langsung telah melibatkan orang tua dalam pemantauan dan penilaian terhadap perkembangan ahlak dan kepribadian anak. 
Ahlakakan terbentuk secara efektif melalui pembiasaan dan pengkondisian. Oleh karena itu untuk menilai ahlak seseorang, tetntunya tidak hanya sebatas pada aspek kognitif lewat lembaran kertas. Tetapi yang lebih utama dalam menilai ahlak seseorang melalui pengamatan terhadap sikap dan perilaku anak sehari-hari, baik dalam lingkungan sekolah, keluarga maupun di masyarakat.

Di MIS Modern Sahid, penilaian terhadap ahlak anak yang utama dilakukan melalui pengamatan oleh guru terhadap sikap dan perilaku anak sehari-hari terutama di lingkungan sekolah. Tidak ada instrumen khusus yang digunakan untuk mengamati sikap dan perilaku siswa, tapi dilakukan secara spontan namun rutin setiap saat ketika anak di sekolah. Pengamatan terhadap ahlak siswa tersebut sudah merupakan suatu rutinitas dan kewajiban bagi seorang guru di sekolah.

Adapun aspek yang dinilai antara lain: 1) Baca Tulis al Qur'an, 2) Kedisiplinan; ketepatan waktu masuk kelas, 3) Tanggung jawab mengerjakan tugas (PR, penylelesaian tugas di kelas, dsb.), 4) Ketaatan beribadah; sholat Dhuha, sholat Dhuhur dan puasa, 5) Kerapihan; pakaian, buku, dsb. 6) Ketertiban; sholat, berbaris ketika mau masuk kelas, dan pengerjaan tugas. 7) Kesopanan; sikap terhadap guru, terhadap teman, dan juga terhadap lingkungan. 8) Kejujuran; misal uang pembayaran sekolah. 9) Toleransi; pergaulan dengan sesama teman di sekolah. 10) Ketekunan; penyelesaian pekerjaan. 11) Kemandirian; penyelesaian pekerjaan. 12) Kreatifitas; misal dalam pelajaran Seni Budaya dan Keterampilan. 13) Pergaulan antar siswa, 14) Kegemaran membaca, 16) Kepedulian terhadap sesama, dan 17) Keseriusan mengikuti upacara

Nilai-nilai tersebut merupakan bagian dari penilaian secara keseluruhan pada pertengahan dan akhir semester, serta akhir tahun. Artinya, dalam penilaian yang sifatnya kognitif melalui tes sumatif, juga dipertimbangkan aspek-aspek sebagaimana disebutkan di atas.

\section{PENUTUP}

\section{Kesimpulan}

Dari uraian di atas, maka dapat disimpulkan mengenai pembentukan karakter (ahlakul karimah) anak di MIS Modern Sahid Bogor. Pandangan pimpinan pondok tentang pembentukan karakter anak, bahwa dalam agama Islam sudah ada istilah yang lebih komprehensif dan universal dibanding karakter yaitu ahlakul karimah (akhlak mulia). Ahlakuk karimah dan pondok (madrasah), keduanya merupakan simbiosis dan melekat dalam proses pembelajaran sehari-hari. Pendidikan karakter atau ahlak mulia melalui sekolah merupakan usaha mulia yang terus ditekankan dan dikembangkan. Oleh karena itu, sekolah tidak hanya bertanggungjawab dalam mencetak peserta didik yang unggul dalam ilmu pengetahuan dan teknologi, tetapi yang lebih penting adalah pembentukan jati diri, karakter dan kepribadian yang Islami. Hal ini sesuai dengan visi yang dicanangkan oleh Pondok Pesantren Modern Sahid, kemudian visi tersebut diimplementasikan melalui kebijakan-kebijakan yang diterapkan dalam proses pembnelajaran di lingkungan pondok termasuk di MIS Modern Sahid.

Pandangan tersebut kemudian mendasari pada kegiatan belajar mengajar sebagai upaya pembentukan ahlakul karimah direncanakan/ diprogramkan dengan baik dan profesional, melalui: 1) Pengintergrasian ke dalam setiap mata pelajaran, bertujuan untuk memperkenalkan nilai-nilai pendidikan karakter di setiap mata pelajaran, 2) Melalui program kokurikuler dan ekstrakurikuler sebagai sarana pengembangan diri dan kegiatan pembiasaan, dan 3) Pengkondisian, baik secara fisik maupun non fisik.

Dalam pelaksnaannya melalui berbagai tahapan, mulai dari kegiatan pembelajaran, penerapan pendidikan karakter pada pelaksanaan pembelajaran dimulai dari penyususunan Rencana Pelaksanaan Pembelajaran (RPP). Dalam setiap penilaian, selalu dimun- 
culkan secara eksplisit indikator ataupun kriteria nilai budaya dan karakter yang diharapkan. 2) Pengembangan Budaya Sekolah dan Pusat Kegiatan Belajar, melalui: kegiatan rutin, kegiatan spontan, keteladanan, dan pengkondisian, 3) Kegiatan Ko-Kurikuler dan atau Kegiatan Ekstrakurikuler.

Penilaian terhadap ahlak dilakukan melalui pengamatan oleh guru terhadap sikap dan perilaku anak sehari-hari terutama di lingkungan sekolah. Namun demikian, tidak ada instrumen khusus yang digunakan untuk mengamati sikap dan perilaku siswa, tapi dilakukan secara spontan namun rutin setiap saat ketika anak di sekolah. Pengamatan terhadap ahlak siswa tersebut sudah merupakan suatu rutinitas dan kewajiban bagi seorang guru di sekolah.

\section{Rekomendasi}

Pendidikan karakter atau ahlakuk karimah sangatpentingditerapkandemimengembalikan karakter bangsa Indonesia yang sudah mulai luntur. Dengan dilaksanakannya pendidikan karakter di sekolah dasar (SD dan MI) diharapkan dapat menjadi solusi atas masalahmasalah social yang terjadi di masyarakat. Oleh karena itu, pelaksanaan pendidikan karakter di sekolah terutama di MIS sahid Bogor perlu terus dikembangkan dan ditingkatkan, baik dalam proses pembelajaran (kegiatan belajar), pengembangan budaya sekolah, pembiasaan dan pengkondisian, kegiatan ko-kurikuler dan atau ekstrakurikuler serta kegiatan keseharian di rumah dan masyarakat.

Dalam perencanaan pembelajaran, hendaknya para pendidik lebih teliti lagi dalam menetapkan indikator nilai-niai karakter, dan disesuaikan dengan materi yang diajarkan.

\section{SUMBER BACAAN}

An-Nahlawi, Abdurrahman, Pendidikan Islam di Rumah Sekolah dan Masyarakat,Jakarta: Gema Insani Press, 1995.

Balai Litbang Agama Jakarta (2009). Pendidikan Agama Islam dalam Perspektif Multikul- turalisme. Jakarta: Balai Litbang Agama Jakarta bekerjasama dengan PT. Saadah Cipta Mandiri.

Kertajaya, Hermawan, 'Grow With Carracter; The Model Marketting', Jakarta: PT.Gramedia Pustaka Utama, 2010.

Kosoema A. Doni, Pendidikan Karakter Strategi Mendidik Anak di Zaman Global, Jakarta: Grasindo, 2010.

Masnur, Muslich, 'Pendidikan Karakter Menjawab Tantangan Kritis Myltidimensional', Jakarta: Bumi Aksara, 2011.

Nasir, Mohd., Ph.D. "Metode Penelitian", Jakarta, Ghalia Indonesia, 1988.

Profil MIS Sahid Tahun Pelajaran 2012/2013

Pusat Pendidikan Islam Internasional Sahid, Eka Dasawarsa Pondok Pesantren Modern Sahid, Bogor, 2010.

Pusat Kurikulum, Pengembangan Pendidikan dan Budaya Bangsa, Kementerian Pendidikan Nasional tahun 2010.

PP Nomor 55 tahun 2007, pasal 3 ayat 2; Pengelolaan Pendidikan Agama dilakukan oleh Menteri Agama

Tim Peneliti Balai Litbang Agama Jakarta, "Pendidikan Karakter di Madrasah", Jakarta: 2013

Tim Penyusun, Bahan Pelatihan Penguatan Metodologi Pembelajaran Berdasarkan Nilai-Nilai Budaya Untuk Membentuk Daya Saing Dan Karakter Bangsa: Pengembangan Budaya dan Karakter Bangsa, Jakarta: Pusat Kurikulum Badan Penelitian dan Pengembangan Kementerian Pendidikan dan Kebudayaan, 2010

Tim Penyusun, Pedoman Pelaksnaan Pendidikan Karakter: Berdasarkan Pengalaman di Satuan Pendidikan Rintisan, Jakarta: Pusat Kurikulum dan Perbukuan, Badan Penelitian dan Pengembangan Kementerian Pendidikan dan Kebudayaan, 2011

Tim Penyususun, Rencana Aksi Nasional (RAN) Pendidikan Karakter, Kementerian Pendidikan dan Kebudayaan, 2010

Undang-Undang Nomor 20 Tahun 2003 tentang Sistem Pendidikan Nasional. 